\title{
Reconstruction of Instructional Material for Christian Higher Education; A Way of Strenghtening Attitude Upon Fear of God
}

\author{
Lince Sihombing \\ IAKN Tarutung \\ mutiarafoundation@yahoo.co.id
}

\begin{abstract}
This article purposively deals with the research result and its implication in human life. The conducted research belongs to ethnography research which is purely applied qualitative method by using social-involving approach coring on the problem of the research namely "How to reconstruct instructional material for Christian higher education?". Technique of sampling was done by using purposive sampling, by selecting certain informants for certain purposes. Data gathering was done by distributing questionnaire, interview, and observation. Data analysis was done by using descriptive qualitative analysis. The research result showed that the attitude/character of the students can be well-formed and sharpened or strengthened throughout reconstructing the instructional material that was taught to the learners. It was found that the bad character of the murderer student at the vocational school in Manado city upon his died-killed religious teacher, was caused by the school learning schedule that was not suitable for students circumstances regarding character building for all around the school. The novelty of the research bearing to the human life is, that learning material is the essential part of education to design.
\end{abstract}

Keywords: Reconstruction of Christian education material, Instruction in higher education, Strengthening Christian attitude, Fear of God

\section{Introduction}

The news about a teacher murdered by his own student in Manado exactly at a vocational school, became booming or viral all around the world, especially around Indonesia, either by electric media or printed media. The reason of the student killed his teacher was actually trivial. The religious teacher reminded/rebuking the two students who were smoking while sitting - after having punishment given by the school for being late to school. Actually there are two students who were reminded/rebuking by the religion teacher regarding that smoking in the school and around during the learning hours is not allowed. One of them was rejected to rebuke by the teacher, he went home but not to his house, but to his family's home, and taking a knife in $25 \mathrm{~cm}$ length - back to school, looking for and chasing religious teachers who made him angry - because he did not receive being rebuked - killed him repeatedly to death. After having interrogation, it was found that the murderer was drunk a day before the event happened. 


\section{Methodology}

The conducted research belongs to ethnography research which is purely applied qualitative method by using social-involving approach. Technique of sampling was done by using purposive sampling, by selecting certain informants for certain purposes. Data gathering was done by distributing questionnaire, interview, and observation.

It was found that reconstruction of Christian religious education learning process in high education was done to sharpen the efforts to improve the quality of learning outcomes. Learning outcomes are mentioned qualified if the learner shows a significant change in three aspects at the same time, they are : improving the learner's skills or ability, improving positive attitudes towards something learned, and permanently embedded knowledge to learning material. Therefore, concerning about religious education that is correlated to being an Indonesian citizen can be illustrated as a driver who adheres to traffic rules, that person will obtain a driver license after passing a traffic test, driving a car according to driving safety instructions and knowing clearly when to overtake a car in which his body inside but thinking outside, from which side of the road he had to go ahead and what signs to follow up, such as turning on the turn signal lights and so on.

\section{Result and Discussion}

There are 4 anomalies that make this murder became a proof that Indonesia, especially the Indonesian society and the Indonesian education world are really in an era of disruption. The era of significant disruption has taken place in a radical change of good values that appears in the form of chaos. These anomalies are:

a) The Indonesian Legal Corporation was shocked. The reason is, that generally killers must be put to death based on the law. But the death penalty is set for adult offenders. As the matter of fact, in this case, the killers was not in a cluster of adult, but teens instead namely 16 . Can the murderer be sentenced to death? Certainly there will be a chaos in deciding penalties for such a case.

b) The school stated in this case was a vocational school majoring on agriculture that allowed the students to smoke, having food and drinks at a certain time it was break time.

c) Student who was labeled as murder in this school was also as smoker and alcoholic drinker, as well.

d) Society around the school has lost social sensitivity or empathy for others. It was summed up from the reconstruction taking on the murder incident. The reconstruction was carried out in the school yard - there were 22 scenes of the tragedy that was reconstructed in the yard, it means that the religious teacher took a long time to struggle alone of maintaining his breath to live, and no one dare to help him.

Based on the 4 anomalies above, it can be concluded that education, especially religious education has failed to form positive character concerning Christian characters. Why is it said so? Because his actions are really beyond the limits of reasonableness. Derived from the matter, It is natural that one of the teacher function is reminding, rebuking, educating, and so forth in or outside the school. Dealing with Christian characters, the religious attitude of the students did not even show an attitude of fear of God. 
Indeed, many reasons why students to behave in lack of characters like; parents who let the irregularities take place at the children action, assumed that one day things would change for the better; the involvement of students with an environment that does not help them to have a positive character; learning process system for each subject, including religious education precisely, also does not support the formation of a positive character on the basis of Christianity which fails to support the formation of Christian values for students of the three causes mentioned above. The third point to be discussed bearing in mind at this point is related to The title of this paper namely; The Reconstruction of instructional material for Christian higher education as a way of strengthening Christian Attitude upon fear of God.

Based on the data analysis, it was found that teachers who teach Christian Religious Education (PAK) in secondary and lower education are basically graduates from theological schools called STT (Theological College) which are divided into 2 namely STT that are managed by the state called STAKPN / STAKN and IAKN, while those managed by the private sector are approximately 287 campuses such as STT HITS, STT Periago, STT Moriah and others. From several study programs managed by various STTs, there is one study program that has always been a mainstay namely the Christian Religious Education (PAK) study program S1 (under graduate level) and S2 (graduate level). Those who graduate from PAK study program are dominantly filling vacancies to become Christian religion teachers / lecturers for senior, junior, and elementary, PAUD schools, both state and private ones.

Tracing the books of Christian religious education, it can be stated that it is such a curriculum of which the content is a unity of educational material that well-prepared towards tailoring the candidate of teachers/lecturers of PAK. On the other hand, Christian Religious Education for non STT students is more about the concept of knowledge not practice (see the book of Matakuliah Wajib Umum PAK by General Directorate of Education, Research and Technology Ministry of Republic of Indonesia, see Sihombing, Lince [1].

According to Barret [2], the content of learning material should be in parallelized within the learners' need to be taught so that they are able to actualize the knowledge they earned in daily life. Based on the data display that the same thing also happened to the Christian Religious Education book used at STKIP Melawi campus. One of the material contained in the book is about Sin. But what is learned about sin is nothing more than a concept of sin which only serves as a knowledge enrichment not a skill / psychomotor for learners as people who after reading about this sin have really changed. This is evident from the material packaged as a discussion for this sin material such as: What is sin?; What is the form of sin in the Old Testament; What is Hamartana in the New Testament; And What is the result of damage to human relations with God?

By the concept of learning, it is believed that lecturers in Religion courses do not have the space to make this material actualized through concrete events such as, what are examples of sinful acts in the present - for instance, smuggling incidents committed by the presidential director of Garuda, How to prevent such an act? A qualified teacher is always well-prepared on the content of material which will be transferred to his learners before teaching, and the content itself is on the basis of learners' needs, see Gene[3].

It is also the same with PAK book for students of theology, they practice with PAK books intended for high school students entitled Pendidikan Budi Pekerti. It was seen from the list of contents, from the 14 chapters of the contents of the book, one of them is Chapter IV: Strong families give birth to strong personalities. These candidate teachers practice with material intended for class XI high school students in semester I. There are several indicators to be studied but there is no topic that talks about how to educate children in the family for the purpose of preventing them from having negative characters. It is precisely to emphasize that 
educating the children to be responsible to parents, making commitments to respect parents. By comparing this with the events of vocational students who killed the teacher it is clearly seen that the students who are nurtured under a well-formed characters are usually respecting parents, behaving in good manner, respecting teachers and all the human being, and so forth regarding positive characters. Concerning about the character regarding students under the teachers controlling, Sommer, Carl claims that teachers are precisely on their position as educators structuring and organizing the learners behavior as to strong characters to behave to actualize the knowledge they earn in daily life [4].

In other words, the topics presented in the religious books, place the child is like an empty doll who has just come out of the factory within his teacher temporarily forces him to do with all the instructions so that the child does as he wants without resistance. From the three books listed above, 2 for students who study in non-religious majors, 1 for religious majors found a common thread that any PAK material taught to students is of the same nature, for instance to assume learners both high school / junior / senior high school students. Moreover, the students are a piece of white paper which must be equipped with all kinds of spiritual weapons so that as expected of the 3 PAK books, they will have qualified Christian morals not evil instead, do not act radically and so on. It is not easy to change everything in a rush time as the Minister of Education; Nadiem Makarim wants to, that education is precisely Christian religious education (PAK) should place students in the position of:

a) Discussion as a learning model because only by discussing the teacher / lecturer knows that each student has a different perspective and all of these different perspectives is true.

b) Adjusting the methods of teaching to their way of life. Actually, teaching referred to the methods used by the teachers, one of them can be started by discussion method as explained above. When one group presents the results of their assignments, the other group listens with the occasional opportunity for other groups outside the presenter to present their work. When this group succeeds in explaining the results of their work, the other group answers their questions and put forward the actual position by the lecturer. It should be realized that the ability to convey information by each student is actualized through the opportunities provided by the lecturer. It is also in the same tone with Splett that engaging the students within the activity during the learning process is able to raise their self-confidence and ability up [5].

\section{Conclusion}

a) The aim of studying religious subject (Christian Education) to immerse permanently students' attitude upon fear of God

b) The results of having fear of God attitude: Students (secondary level and university) are able to actualize good life; and Students are reluctant to do wrong action, crime and the like.

c) The Root of the Problems: the text books of Christian education are not matched to the needs of immersing the attitude of fear of God, it was proved from the books used for educating. Christian religion to secondary and higher education, the contents of the books merely place students' psychomotoric/skill in conducting the religion as the trivial. 


\section{Implication}

a) The teachers can use instruction of Christian Religion Education material and discuss it with the students first in the class.

b) There is a chance for the teachers to ask the students to experience the way to avoid the negative effect by offering them real good characters out of the class.

c) The teacher can drill the students when they back to the class and tell them how to report their finding(s) based on Christian Religion Education materials assigned.

\section{References}

[1] Sihombing, Lince. 2017. Bunga Rampai Proses Pembelajaran dari Penanganan Klasikal ke Komunal. STAKPN Tarutung Press. Tarutung

[2] Barrett, Peter et al. 2015. The impact of classroom design on pupils' learning. retrieved by May 2018, Elsvier Journal: https://www.sciencedirect.com/science/artice/pi/S0360132315000700

[3] Klann, Gene. 2007. Building Character. John Weley \& Son Inc. U.S

[4] Sommer, Carl. 2006. Character under Attact. Advance Publishing Inc. Houston

[5] Splett, Joni et al. 2015. Between-Teacher variance student's teacher-rated risk for emotional, behavioral, and adaptive functioning. Retrieved by June 2020, Elsvier Journal: https://www.sciencedirect.com/science/artice/pi/S002244520300224 